\title{
Carbon reduction with solar energy in cities
}

\author{
E. Ö. Aktuğlu Aktan \\ Yildiz Technical University, Turkey
}

\begin{abstract}
One of the carbon reduction strategies is using solar energy (power). Solar energy is the most popular renewable energy and an essential technology for powering our cities in the future. It will transform us from fossil fuel dependency to renewable energy for sustainable cities.

Sunlight is very important for urban design and architecture. Solar energy has been used by humans for thousands of years. They used orienting building toward the south for more light and heat. Now, using and storing maximum sunlight and heat is a significant design criterion for cities and streets. Solar energy is the technology used to harness the sun's energy and make it useable. Today, the technology produces less than one tenth of one percent of global energy demand.

The objective of this paper is to explain the importance of using, firstly, passive solar energy design criteria in cities and to give cases where solar energy is used for a sustainable lifestyle (e.g. Masdar City, Dongtan, King Abdullah Financial District, Crystal Island, ZED Factory Projects and Zira Island).

As a result, the design of cities, streets and buildings will change. For example, the roofs will be very important for storm-water. Some buildings have green roofs. But in the future, solar panels will replace roofs. Street orientation, ventilation and ratios are essential for radiation. Cities will be smarter and more sustainable than today towards zero-carbon energy.
\end{abstract}

Keywords: carbon reduction strategy, renewable energy, solar energy, sustainable cities.

\section{Introduction}

Sustainable development can be defined as that which meets the needs of the current generation while leaving sufficient resources for the current generation while leaving sufficient resources for the needs of future generations. 
The EU aims to get $20 \%$ of its energy from renewable sources by 2020 . Renewables include wind, solar, hydro-electric and tidal power as well as geothermal energy and biomass. More renewable energy will enable the EU to cut greenhouse emissions and make it less dependent on imported energy. And boosting the renewables industry will encourage technological innovation and employment in Europe [1]. On 17 October 2012, the Commission published a proposal to limit global land conversion for biofuel production, and raise the climate benefits of biofuels used in the EU [2].

Carbon reduction (carbon neutral), or having a net zero carbon footprint, refers to achieving net zero carbon emissions by balancing a measured amount of carbon released with an equivalent amount sequestered or offset, or buying enough carbon credits to make up the difference. It is used in the context of carbon dioxide emission processes associated with transportation, energy production, and industrial processes such as production of carbon neutral fuel [3].

\section{Renewable energy}

Renewable energy is a socially and politically defined category of energy sources. Renewable energy is generally defined as energy that comes from resources which are continually replenished on a human timescale such as sunlight, wind, rain, tides, waves, plant growth, and geothermal heat, as the International Energy Agency explains [4, 5, p. 9].

The purpose of using renewable energy is to provide energy with reduced emissions of greenhouse gases. The concentration of $\mathrm{CO}_{2}$ in the atmosphere remained below 280 parts per million (ppm) for 800 thousand years until the start of the Industrial Revolution in the eighteenth century. The concentration has risen from $280 \mathrm{ppm}$ in 1780 up to $400 \mathrm{ppm}$ in 2013. The effects of this accelerating trend on our future environment are unknown, but scientists are debating the effects of these trends and the risks of reaching tipping points that may not be reversible [6].

\section{Solar energy and design}

In this paper, main objective is solar energy usage for designing sustainable cities.

The word solar stems from the Roman word for the god of the sun, Sol. Therefore, the word solar refers to the Sun and "solar power" is power from the Sun. Solar technologies are broadly characterized as either passive solar or active solar depending on the way they capture, convert and distribute solar energy. Passive solar techniques include orienting a building to the sun, selecting materials with favourable thermal mass or light dispersing properties, and designing spaces that naturally circulate air. Active solar techniques include the use of photovoltaic panels and solar thermal collectors to harness the energy [7]. 


\subsection{Passive solar energy and design}

Solar energy has been used by humans for thousands of years. For example, ancient cultures used energy from the sun to keep warm by starting fires with it. They also kept their homes warm through passive solar energy designs. Buildings were designed so that walls and floors collected solar heat during the day that was released at night to keep them warm. If you have ever stood in the sun to get warm then you too have utilized solar thermal energy [8]. Similarly, absorbent plates on a roof can heat liquid in tubes that supply a house with hot water.

There are many practical applications for solar power that are in use today. Passive solar home designs utilize heat energy. By slanting windows in a house and facing them to the south you can control the heat energy that enters the house. During the winter when the sun is low in the sky it shines into the window to warm and illuminate the house. During the summer when the sun is high in the sky the slant of the windows keeps the sunshine out so that the house stays cooler [9].

Homes constructed as passive solar design use the natural movement of heat and air to maintain comfortable temperatures, operating with little or no mechanical assistance. It's called passive solar because the design of the home maximizes the benefits it receives from the sun with standard construction features. Passive solar takes advantage of local breezes and landscape features such as shade trees and windbreaks, and uses a simple system to collect and store solar energy with no switches or controls $[10,11]$.

Although, building a passively designed solar home takes careful planning, the task is relatively simple - if five basic solar design principles are used:

- Orientation;

- Overhangs and shading;

- Insulation;

- Windows;

- Thermal Mass.

Actually, the first four principles shouldn't be reserved for only the passive solar home - they work well with any home, custom-built or tract. Passive design features, such as shading or insulation, can be used to improve your home without major renovation. Windows and thermal mass, however, are best done during new construction or major remodelling.

And speaking of thermal mass, passive designed homes also include this unique feature, not found in conventional homes. Thermal mass is any construction material that allows a passive-designed home to collect, store and distribute the sun's energy. Passive systems can be built with different configurations of energy-saving features and a variety of conventional and unique architectural styles. Rather than being totally different, a carefully designed and constructed solar home is more of a "rearrangement" of the same construction materials needed to build any home.

Building to take advantage of solar energy need not cost any more than building a comparably sized non-solar conventional home. A home that is 
properly oriented, tightly constructed, well insulated, and has operable windows for air circulation is both comfortable for the occupants and easy on the wallet. You can call it passive design or just smart construction $[10,11]$.

\subsubsection{Impact of the street orientation on insolation}

The streets' orientation affects the solar exposure of open areas and buildings as well as the comfort of people walking in the streets. In moderate climates, the objectives on this subject are rather complicated: to provide maximum shade in summer and maximum impinging solar radiation in the winter. These requirements are difficult to satisfy, as in the summer, the sun stands high on the sky and thus reached the street level easier than in winter, when the radiation angle is considerably lower and the street better protected by buildings from direct solar radiation. There is only deciduous vegetation in form of robust, solar-friendly trees that is able to oblige the human physical comfort demand, providing shade in summer and letting insolation penetrate through the thin branches in the winter. In this case, the South-North orientation of the streets would prove to be most convenient, allowing sunlight reaching the streets' ground level in the winter [12, p. 27].

As streets cover around a quarter of urban areas, designing streets is a key issue in a global approach for an environmental urban design. The geometry of streets (H/W and $\mathrm{L} / \mathrm{W}$ ratios) and orientation directly influence the airflow and solar access in urban canyon and therefore thermal comfort at pedestrian level. A wider street provides better mixing of air and consequently better airflow in the urban canyon. In addition, better ventilation could be obtained in a street with various building heights. Moreover, the $\mathrm{H} / \mathrm{W}$ ratio affects the quantity of solar energy obtained by street surfaces (facades, roofs and ground). Decrease of the $\mathrm{H} / \mathrm{W}$ ratio increases solar access in the street. Street orientation hardly influences the amount of solar radiation of the canyon; it causes differences in the distribution of the total radiation over the different street surfaces. Street orientation significantly influences the diurnal and seasonal pattern of irradiation of the street surfaces and it is more affective on the vertical surfaces of the street. Therefore, in order to provide a pleasant microclimate in urban areas, designing urban streets in a way which brings about appropriate airflow and utilize solar access is vital and essential. This could affect global climate and energy consumption of buildings [12, 13].

When aiming to alleviate the impacts of the summer heat waves, however, the heating-up effect of the urban canyons must be considered. A study by Herrmann and Matzarakis [12, 14, pp. 525-526] showed that a North-South oriented street reaches very high temperatures, while in the case of East-West oriented urban canyons, the temperatures were considerably lower. Although this study has been conducted on an idealized canyon model, it implies that East-West oriented street canyons (and canyons oriented in a small angle to this direction) are optimal in moderate climate [12, p. 27].

Most passive solar guide books recommend a southerly orientation. The consensus seems to be that within $20^{\circ}-30^{\circ}$ of due south is best [15, p. 307]. 


\subsubsection{Solar radiation and its impact on green areas and built environment}

The air in green areas is cooler than the air in built-up areas covered by asphalt or concrete [12, p. 17; 16, p. 307]. The cooling effect of plants caused by evapotranspiration is apparent in the figure 1. The pictures show that the leaves of the plants are, because of transpiration, visibly cooler than the surrounding soil [12, p. 17; 17, p. 27].
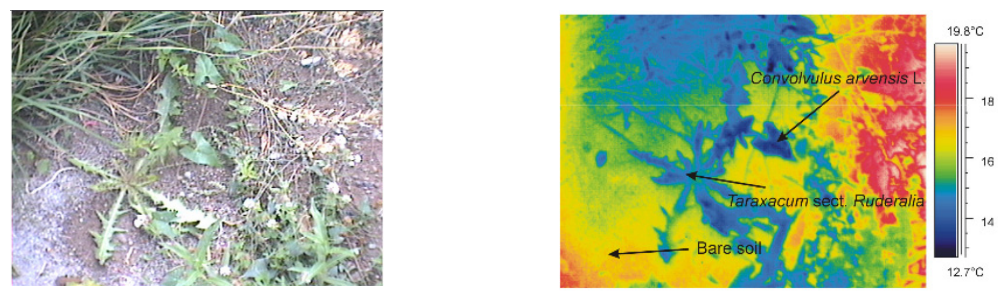

Figure 1: Photographs of thin vegetation in the infrared spectrum and in the visible spectrum. The bare surface of the ground is visibly warmer than the surface of the leaves cooled by transpiration. (Třebon̆, Czech Republic, 12 July 2002, 10:00 hrs) [17, p. 32].

The temperature of the roofs and facades of homes exceeds $30^{\circ} \mathrm{C}$, whereas the temperature of the trees in the park is around $17^{\circ} \mathrm{C}$ (figure 2) Vegetation actively cools through the evaporation of water. Vegetation, particularly forests, has a darker color and thus a lower reflectance (albedo) than most other surfaces (clay, sand, white painted walls etc.). This difference in reflectance is sometimes interpreted as meaning that forests warm the Earth's surface. From figure 2, it is obvious that plants, independently of reflectance, cool through transpiration. Figure 2 again shows that the effect of reflectance is much lower in comparison with the effects of transpiration [17, pp. 27-28]. We can thus conclude that evapotranspiration is more effective than albedo [12, p. 19].

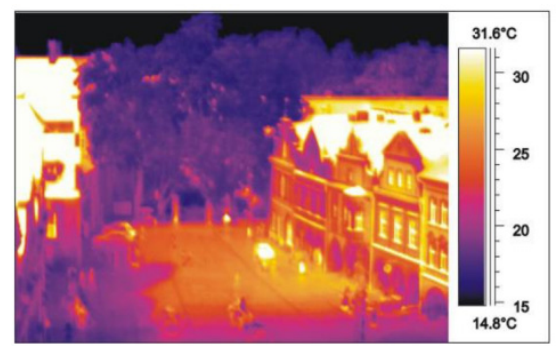

Figure 2: Photograph of the square and adjacent park in Třeboň, Czech Republic, taken with a thermal camera The differences in temperatures between the vegetation, facades and roofs of the houses are visible [12, p. 19; 17, p. 33]. 
Therefore, water surfaces, soil saturated with water and vegetation have all significant cooling effect and air-conditioning capability [17, p. 15]. The imperative message thus is that the design of surfaces in the urban environment needs to support evapotranspiration as main priority in urban design.

Translated into designer's language, trees, vines and high dense shrubs next to walls, pergolas and roof vegetation have impacts on the climate on and around buildings - they protect by their shading and cooling effect from over-radiation, while certain ventilation is still provided [16].

Transpiring plants, especially trees, is the perfect natural air-conditioning system. On the crown of a tree of about $10 \mathrm{~m}$ in diameter, with a surface area of $80 \mathrm{~m}^{2}$, there falls each day about $450 \mathrm{kWh}$ of solar energy $\left(4-6 \mathrm{kWh} / \mathrm{m}^{2}\right)$. Part of the solar energy is reflected, part is absorbed by the soil and part is converted into heat. If such a tree is well stocked with water, particularly when planted over vegetated and non-sealed surfaces [18], it evapotranspires some 400 litres of water each day, consuming about $280 \mathrm{kWh}$. This amount of energy represents the difference between the shadow of a tree (absorbed and reflected energy is $170 \mathrm{kWh}$ ) and the shadow of a parasol with the same diameter (absorbed and reflected energy is $450 \mathrm{kWh}$ ). In the course of a sunny day, then, such a tree cools with a power equal to $20-30 \mathrm{~kW}$, power comparable to that of more than 10 air-conditioning units [17, p. 27].

Additionally, ground cover by plants around a building reduces the reflected solar radiation emitted toward the walls, thus lowering the heat gain in the summer [12, p. 17].

\subsubsection{Green roof}

Vegetation covers on roof surfaces. There are two types: extensive and intensive. Extensive green roofs (also referred to as eco-roofs or living roofs): thin soil layer with horizontally spreading, low-growing vegetation cover over entire roof surface that adds minimal loads to structure; serves as ecological storm-water management control by eliminating or delaying runoff. Also effectively reduces temperatures of the roof surface by absorbing heat from the sun, which may reduce the urban heat island (UHI) effect. Intensive green roofs (also referred to as traditional roof garden): thick soil layer or planters with vegetation, such as trees and shrubs that requires intensive care and maintenance; add substantial loads to buildings structure [19, p. 448]; but also being more efficient in term of evapotranspiration and thus in temperature lowering effects, since intensive green roofs often require increased irrigation (Marco Schmidt, consultation) [12, p. 62].

\subsection{Active solar energy and design}

Solar energy applies energy from the sun in the form of solar radiation for heat or to generate electricity. Solar powered electricity generation uses either photovoltaic or heat engines (concentrated solar power). A partial list of other solar applications includes space heating and cooling through solar architecture, day-lighting, solar hot water, solar cooking, and high temperature process heat for industrial purposes [20]. 
The sun provides Earth with two major forms of energy, heat and light. Some solar powered systems utilize the heat energy for heating while others transform the light energy into electrical energy (electricity) [9].

Active solar systems use mechanical devices such as pumps and fans to move heat from collectors to storage or from storage to use. Photovoltaic panels (solar panels) that collect solar energy, turning it into electricity, are also considered an active solar system $[10,11]$.

Solar energy is lauded as an inexhaustible fuel source that is pollution and often noise free. The technology is also versatile. But solar energy doesn't work at night without a storage device such as a battery, and cloudy weather can make the technology unreliable during the day. Solar technologies are also very expensive and require a lot of land area to collect the sun's energy at rates useful to lots of people [21].

Photovoltaic cells, or solar panels, are found on things like spacecraft, rooftops, and handheld calculators. The cells are made of semiconductor materials like those found in computer chips. When sunlight hits the cells, it knocks electrons loose from their atoms. As the electrons flow through the cell, they generate electricity [21].

The discovery of photovoltaic occurred in 1839 when the French physicist Edmond Becquerel first showed photovoltaic (PV) activity. In 1921 Albert Einstein received the Nobel Prize for his theories on the photoelectric effect. Solar cells of practical use have been available since the mid 1950s. By 1960 Hoffman Electronics increased commercial solar cell efficiencies to as much as $14 \%$ and today researchers have developed cells with more than $20 \%$ efficiencies. $20 \%$ efficient means that out of the total energy that hits the surface of a solar cell; about $20 \%$ is converted into usable electricity.

The first long-term practical application of PV cells was in satellite systems. In 1958 the Vanguard I, was launched into space. It was the first orbiting vehicle to be powered by solar energy. Photovoltaic silicon solar cells provided the electrical power to the satellite until 1964 when the system was shut down. The solar power system was so successful that PV's have been part of worldwide satellite space programs ever since. The sun provides endless nonpolluting energy to the satellite power systems and demand for solar cells has risen as a result of the telecommunications revolution and need for satellites.

The energy crisis and oil embargos of the 1970s made many nations aware of their dependency on controlled non-renewable energy sources and this fuelled exploration of alternative energy sources. This included further research into renewable sources such as solar power, wind power and geothermal power.

An economic breakthrough occurred in the 1970s when Dr. Elliot Berman was able to design a less expensive solar cell bringing the price down. The huge cost savings opened up a large number of applications that were not considered before because of high costs. These applications included railroads, lighthouses, off-shore oil rigs, buoys, and remote homes. For some countries and many applications, solar energy is now considered a primary energy source, not an alternative [8]. 
There are vehicles that run on solar power. Some have PV panels as a direct power source that converts light energy into electricity to power their motors. Since those cars will not run when the sun is not available it is more practical to have a car powered by batteries that can be recharged with solar energy [9].

On a much larger scale, solar thermal power plants employ various techniques to concentrate the sun's energy as a heat source. The heat is then used to boil water to drive a steam turbine that generates electricity in much the same fashion as coal and nuclear power plants, supplying electricity for thousands of people [21].

\section{Case studies}

The cities listed below provide examples of future solar cities that explore the use of renewable energy at a city scale for a sustainable development [22].

Masdar City Abu Dhabi, United Arab Emirates

Masdar City is the world's first (proposed) zero-carbon city. It uses building design, layout, and building materials to generate an energy efficient city, all while utilizing traditional building designs to maximize sunlight and wind potential. The city will run on wind (a wind turbine farm), solar, and hydrogen power, in addition to traditional electricity. The city will utilize public transportation, and citizens will either walk or use bicycles as opposed to cars.

The master plan, based on several analytical computer evaluations and windtunnel models, proposes narrow streets to protect against the sweltering heat and to keep the street spaces cooler than those outside the city. In limiting street length and influencing street orientation, the "cold island" of Masdar reinterprets traditional local wind towers, ventilating street spaces at night and protecting them against the hot summer winds during the day. "Green fingers" reach through the city from northwest to east to allow for basic ventilation and to catch the cooler east winds. All these efforts ensure that the thermal and visual comfort of the city spaces have a positive direct impact on building loads [23].

\section{Dongtan China}

Dongtan, the sustainable design initiative of Shanghai, will be a self-sufficient energy city featuring zero-energy buildings. The city will run exclusively on solar, wind, and biofuel energy. Building roofs will hold PV cell arrays, and there will be a wind turbine farm outside of the city in addition to smaller ones within the city. Waste will be recycled, and some will be used to create power. The city will be filled with greenery, especially on rooftops to create insulation and to filter rainwater. Traditional building techniques regarding windows and air will allow buildings to remain warm and cool when needed, reducing the need for artificial air control [22].

King Abdullah Financial District Riyadh, Saudi Arabia

In King Abdullah Financial District, temperature will be controlled by traditional building techniques using wind and sunlight. Efficient public transportation will be an integral part of the area and design. Sustainability is achieved through the use of specific building materials, and integrating solar panels, shade, and 
greenery into the design. The design will also minimize water use and waste, and utilize recycled materials and resources [22].

\section{Crystal Island Moscow, Russia}

Crystal Island might as well be a smaller version of the city. Its building is large enough to house around 4000 living spaces, recreational spaces, and a parking structure. The exterior will be covered with solar panels, and additional wind turbines will create energy for the building. Traditional building techniques will naturally ventilate the space, regulate sunlight, and reduce the need for heating or cooling [22].

\section{Tongshan China}

Tongshan is a commuter suburb serving XuZhou a city in North East China. The master plan has been developed to utilize the natural topography of the site and optimize the potential to harvest renewable energies. The gentle slope across the site has been used to channel and pool rainwater run off to provide both amenity and a supply of non-potable water. This landscaped drainage also provides visual amenity and promotes biodiversity across the site. Buildings have been orientated to promote the free flow of prevailing winds through the development combined with the added cooling effect of the pooled water to prevent the urban heat island effect.

Solar orientation of all buildings will provide sufficient PV mounting space to meet annual electricity requirements. The gentle slope across the site has been used to channel and pool rainwater run off to provide both amenity and a supply of non-potable water. This landscaped drainage also provides visual amenity and promotes biodiversity across the site.

Streets between buildings have been raised to provide car parking with linear parks above, again providing amenity for residents whilst hiding the visual pollution of parked vehicles. A 'high street' has been created with residential blocks over two storey of retail leading to a central plaza with communal facilities.

The development comprises 4 typologies 2 multi storey apartment blocks and 2 villa types. All of the apartment blocks are well serviced by public transport links and villas have easy access to the perimeter roads preventing traffic build up within the development. A centralized biomass boiler running on rice husk and heat mainly provides top up hot water and minimal space heating during winter months [24].

\section{Zira Island}

Zira Island is a 1,000,000 sq. meter island. In the Caspian Sea that will soon be developed into an eco-community and sustainably built resort. The carbonneutral eco-island is based on the seven peaks of Azerbaijan and its mountainous ecosystems. Located in the bay of the capital city Baku, Zira Island is a ferry ride away from a growing metropolis and will stand as an example to a region so dependent on oil, that it is possible to live off the wind and sun. The seven peaks will each house a residential development and public space, and there will also be 300 private villas near a golf course in the central valley. Zira's new skyline 
of organic buildings will resemble a mountain range that merges with the natural topography of the island.

Zira Island is sustainable and will use the sun, wind and water to heat and power the island. Heat pumps, which plunge into the surrounding Caspian Sea, will heat and cool the buildings on the island, and solar hot water collectors are integrated into the architecture to provide hot water. Photovoltaics on strategically angled facades and roof tops will generate electricity, and an offshore wind farm will be constructed in the Caspian Sea, utilizing the existing oil platforms and foundations for the new and more sustainable power supply.

Potable water will be provided via a desalination plant, while waste and storm-water will be collected in a wastewater treatment plant and recycled for irrigation. The solid waste will be composted and reused as fertilizer for the island. Many trees and lots of lush vegetation will be planted to create a tropical environment, although no information is provided for how the island will deal with their trash or whether or not they will grow any of their own food [25].

\section{Conclusion}

Sustainable development is an urban development that does not contribute to environmental degradation and climate change; or does in a very low extent [12, p. 64].

If the temperature at night is not cooled down to below $25 \mathrm{C}$, the sleep depth is regeneration function of sleep lost [26, p. 20].

As various sources explain, in urban areas, buildings and paved surfaces have replaced natural landscapes, significantly increasing the rainwater runoff and reducing the natural cooling effects that shading and water evaporation from soil and leaves ordinarily provide. Instead, solar energy is absorbed into roads, buildings' walls and rooftops, causing the surface temperature to become higher than the ambient air temperatures. Meanwhile, tall buildings, closed building blocks and narrow streets reduce airflow and heat the air trapped between them. Waste heat from vehicles, industrial plants, buildings (especially from heating and air conditioners) adds heat to the surroundings, further exacerbating the heating effect. In addition, the urban 'greenhouse' effect contributes with longwave radiation reflected from polluted urban atmosphere. This phenomenon, known as 'urban heat island', can raise air temperature in a city by $10^{\circ} \mathrm{C}$ and even more [12, p. 14].

Increasing the presence of vegeted surfaces in cities in order to retain rainwater on-site to increase water vapour in the air, which in turn lowers surface temperatures, is recommended [27].

The orientation of streets and the urban form [16, 28, and 14] are considered to be the decisive factors in affecting temperatures in cities.

Buildings of the future must be designed and constructed to reduce energy demand. Sustainable design will help to reduce energy consumption but this must be complemented by the generation of energy from renewable sources. 


\section{References}

[1] ec.europa.eu/energy/renewables/index_en.htm

[2] ec.europa.eu/energy/renewables/targets_en.htm

[3] en.wikipedia.org/wiki/Carbon_reduction

[4] Stower, D., The myth of renewable energy, Bulletin of the Atomic Scientists, thebulletin.org, 2011-11-22, Retrieved 2013-10-03, 2011.

[5] IEA Renewable Energy Working Party, Renewable Energy... into the mainstream, 2002

[6] www.icax.co.uk/Environmental_Impact_Renewable_Energy.html

[7] Solar Chimney, Natural Ventilation; Passive Downdraught Evaporative Cooling, Passive Cooling. ICAX, 2007.

[8] www.makeitsolar.com/solar-energy-information/01-solar-history.htm

[9] www.makeitsolar.com/solar-energy-information/03-solar-power.htm

[10] www.consumerenergycenter.org

[11] www.fixr.com/info/passive-solar-design.html

[12] Milosovicova, J., Climate-sensitive urban design in moderate climate zone: responding to future heat waves, Master's Thesis in Urban Design, jm-urbandesign.com/images/Thesis\%20document.pdf, 2010.

[13] Shishegar, N., Street design and urban microclimate: Analyzing the effects of street geometry and orientation on airflow and solar access in urban canyons, 2013.

[14] Herrmann J. \& Matzarakis A., Influence of mean radiant temperature on thermal comfort of humans in idealized urban environments" in Matzarakis, A.; Mayer, H.; Chmielewski, F.-M. (Eds.): Proceedings of the 7th Conference on Biom-eteorology Albert-Ludwigs-University of Freiburg, Germany 12-14 April 2010, pp. 522-527. http://www.mif.unifreiburg.de/biomet/bm7/report20.pdf, 2010.

[15] Littlefair, P., Passive solar urban design: ensuring the penetration of solar energy into the city, Renewable and Sustainable Energy Reviews 2, Pergamon, pp. 303-326, 1998.

[16] Givoni, B., Climate considerations in building and urban design, Van Nostrand Reinhold, New York, 1998.

[17] Kravcik, M., Pokorny, J., Kohutlar, J., Kovac, M., Toth, E., Water from the recovery of the climate - a new water paradigm, Krupa print, Zilina, www.waterparadigm.org, 2007.

[18] Meier, F., Schere, D., Richters, J., Spatial and temporal variability of surface temperature of tree crowns in an urban environment, In; Matzarakis, A., Mayer, H., Chmielewski, F.-M (Eds.), Proceedings of the 7th Conference on Biometeorology. Ber. Meteorol. Inst. Univ. Freiburg No. 20, 428-432, 2010.

[19] Yeang, K., Ecodesign A manual for ecological design, Wiley-Academy, UK, 2006.

[20] en.wikipedia.org/wiki/Renewable_energy

[21] environment.nationalgeographic.com/environment/global-warming/solarpower-profile/ 
[22] megacities.usc.edu/research/solar-cities/example-cities.htm

[23] Thierfelder, A., Schuler, M., "In Situ: Site Specificity in Sustainable Architecture", ed. Mohsen Mostafavi with Gareth Doherty, Ecological Urbanism, Lars Müller Publishers, Germany, pp. 590-597, 2010/2011.

[24] www.zedfactory.com/projects_worldwide tongshan.html

[25] Meinhold, B., Azerbaijan's Carbon Neutral Zira Island, inhabitat.com/ziraisland-by-big-architects, 2009.

[26] Hahn-Herse, G., Erfassung und Bewertung der Kulturlandschaftsqualitäten im Raum Pirna-Riesa, Technische Universität Dresden, Institut für Landschaftsarchitektur, 1997.

[27] Schmidt, M., "Rainwater Harvesting for Mitigating Local and Global Warming. Fifth Urban Research Symposium, 2009: "Cities and Climate Change: Responding to an Urgent Agenda". Marseille, Frankreich, 28-30 June 2009, www.gebaeudekuehlung.de

[28] Emmanuel, R. M.,"An Urban Approach to Climate-Sensitive Design. Strategies for the tropics". Spon Press USA and Canada, 2005. 